$$
\mathrm{S}-1
$$

\title{
Collagen-Related Peptides: Self-Assembly of Short, Single Strands into a Functional Biomaterial of Micrometer Scale
}

\author{
Mabel A. Cejas, ${ }^{\dagger}$ William A. Kinney, ${ }^{*},{ }^{\dagger}$ Cailin Chen, ${ }^{\dagger}$ Gregory C. Leo, ${ }^{\dagger}$ Brett A. Tounge ${ }^{\dagger}$ \\ Jeremy G. Vinter, ${ }^{\ddagger}$ Pratik P. Joshi, ${ }^{\S}$ and Bruce E. Maryanoff ${ }^{\dagger}$ \\ Vascular Research Team, Johnson \& Johnson Pharmaceutical Research \& Development, \\ Spring House, Pennsylvania 19477-0776, Cresset Biomolecular Discovery, Spirella \\ Building, Letchworth, Herts, SG6 4ET UK, and Center for Advanced Microscopy, \\ University of Miami, Coral Gables, Florida 33146
}

\section{Supporting Information}

\section{Pages}

$\begin{array}{ll}\text { Nonstandard Abbreviations } & \mathrm{S}-2 \\ \text { Materials and Methods } & \mathrm{S}-2 \\ \text { Peptide Synthesis } & \mathrm{S}-2 \\ \text { Computational Chemistry } & \mathrm{S}-3 \\ \text { Circular Dichroism (CD) Spectroscopy } & \mathrm{S}-6 \\ \text { Scanning Electron Microscopy (SEM) } & \mathrm{S}-7 \\ \text { Transmission Electron Microscopy (TEM) } & \mathrm{S}-8 \\ \text { Proton NMR Spectroscopy } & \mathrm{S}-9 \\ \text { Dynamic Light Scattering (DLS) } & \mathrm{S}-10 \\ \text { Platelet Aggregation Studies } & \mathrm{S}-11 \\ \text { References and Notes } & \mathrm{S}-12\end{array}$

\footnotetext{
*wkinney1@ prdus.jnj.com

† Johnson \& Johnson Pharmaceutical Research \& Development.

¥ Cresset Biomolecular Discovery.

${ }^{\S}$ University of Miami.
} 


\section{Nonstandard Abbreviations.}

DCM dichloromethane

DIEA $N, N$-diisopropylethylamine

Fmoc (9-fluorenyl)methoxycarbonyl

HBTU 2-[(1H-benzotriazol-1-yl)-1,1,3,3-tetramethyluronium hexafluorophosphate

HOBT 1-hydroxybenzotriazole

NMP $N$-methylpyrrolidone

TFA trifluoroacetic acid

Complete ref 14a: See ref 13 on page S-12.

Materials and Methods. Fmoc-amino acids, HBTU/HOBT, DIEA, NMP and DCM were purchased from Applied Biosystems, Inc. Piperidine was purchased from SigmaAldrich. Fmoc-Gly-Wang resin was from Bachem and Fmoc-Phe-Wang resin from Novabiochem. Peptide 2b [(Pro-Hyp-Gly $)_{10}$ ] was purchased from Peptides International, Inc. MALDI-TOF mass spectrometry was performed at M-Scan Inc. using an Applied Biosystems Voyager-DE PRO Biospectrometry workstation coupled with a Delayed Extraction laser-desorption mass spectrometer with $\alpha$-cyano-4-hydroxycinnamic acid as the matrix. Amino acid analysis was performed at the Molecular Structural Facility of U.C. Davis using a Beckman 6300 Li-based amino acid analyzer. Peptides were $>90 \%$ pure and the peptide content was considered to prepare the solutions for each experiment. Additionally, peptide concentration was confirmed measuring the absorption at $214(\varepsilon=$ $6.0 \times 10^{4} \mathrm{M}^{-1} \mathrm{~cm}^{-1}$ in PBS $)^{1}$ or $215 \mathrm{~nm}\left(\varepsilon=6.5 \times 10^{4} \mathrm{M}^{-1} \mathrm{~cm}^{-1}\right.$ in water). ${ }^{2}$ All peptide filtrations for electron microscopy experiments were performed using Nuclepore filters (0.4- $\mu \mathrm{m}$; polycarbonate membrane) from Whatman, the rest of the filtrations were done using Acrodisc syringe filters $(0.45-\mu \mathrm{m}$; polytetrafluoroethylene membrane) from Pall.

Peptide Synthesis. Peptide 1a was synthesized on an ABI 431 synthesizer using FastMoc chemistry ${ }^{3}$ (0.1 mmol scale) and Fmoc-Phe-Wang resin $(0.74$ mmol/g, 100-200 mesh). The peptide was cleaved from the resin with TFA/triisopropylsilane/water (95:2.5:2.5) for $2 \mathrm{~h}$. HPLC purification was performed in a Phenomenex C-18 reversephase column $(25 \times 5 \mathrm{~cm})$, using a linear gradient of $10-95 \% \mathrm{~B}\left(\mathrm{~A}: 0.2 \% \mathrm{TFA} / \mathrm{H}_{2} \mathrm{O}\right.$; B: $0.16 \% \mathrm{TFA} / \mathrm{MeCN}$ ) over $60 \mathrm{~min}$ at a flow rate of $50 \mathrm{~mL} / \mathrm{min}$. The peptide was obtained as a white powder in $32 \%$ overall yield. MALDI-TOF-MS $(\mathrm{M}+\mathrm{Na})^{+}$calcd for $\mathrm{C}_{138} \mathrm{H}_{185} \mathrm{~F}_{5} \mathrm{~N}_{32} \mathrm{O}_{43}, 3096.3$; found, 3096.8 .

$\mathrm{Ac}$ (Gly-Pro-Hyp) ${ }_{10} \mathrm{GlyOH}$ (2a) was synthesized on an ABI 433A synthesizer using FastMoc chemistry (0.1 mmol scale) and Fmoc-Gly-Wang ( $0.7 \mathrm{mmol} / \mathrm{g}, 100-200 \mathrm{mesh})$. The peptide was cleaved from the resin with 95\% TFA for $2 \mathrm{~h}$. HPLC purification was performed in two Vydac C-18 reverse-phase columns $(25 \times 2.5 \mathrm{~cm})$, using a step gradient of $0-100 \%$ B over $90 \mathrm{~min}\left(\mathrm{~A}: 0.1 \% \mathrm{TFA} / \mathrm{H}_{2} \mathrm{O} ; \mathrm{B}: 80 \% \mathrm{MeCN} / \mathrm{H}_{2} \mathrm{O}\right.$ containing $0.1 \%$ TFA) at a flow rate of $6 \mathrm{~mL} / \mathrm{min}$. The peptide was obtained as a white powder in $34 \%$ 
overall yield. MALDI-TOF-MS $(\mathrm{M}+\mathrm{Na})^{+}$calcd for $\mathrm{C}_{124} \mathrm{H}_{177} \mathrm{~N}_{31} \mathrm{O}_{43}, 2811.3$; found, 2812.2.

$$
\text { S - } 3
$$

Computational Chemistry. The crystal structure of the collagen-like peptide [(Pro-

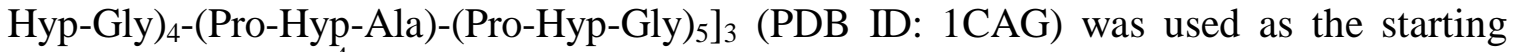
point for modeling. ${ }^{4}$ Since this structure contained a central alanine residue, this residue was first mutated to glycine. The next step was to add the self-assembly units to the Nterminus and C-terminus of each strand of the triple helix. On the N-terminus, the ProHyp segments where replaced with a single pentafluorophenylalanine, phenylalanine, or leucine (Figure S1). On the C-terminus, the glycine residue was replaced by phenylalanine. At this stage, the single unit triple helix was minimized (constrained backbone, OPLS-AA force field ${ }^{5}$, GB/SA water ${ }^{6}$ using Macromodel $^{7}$ ) to relax any strain caused by the modifications. The next step was to construct the self-assembled pair by aligning two of the triple helix units along the triple helix axis. In this step, care was taken to provide a rough alignment of the recognition units.

Figure S1. The original sequence for one strand from the 1CAG crystal structure (A) was modified to the peptides like 1a, 1b, and 1c (B) where $X=$ hydroxyproline, $Z=$ pentafluorophenylalanine (1a), phenylalanine (1b), or leucine (1c). Due to the nature of the crystal structure sequence, the peptides generated for modeling contain one less repeat of the GPX motif.

\section{A: PXGPXGPXGPXGPXAPXGPXGPXGPXGPXG \\ B : ZGPXGPXGPXGPXGPXGPXGPXGPXGPXF}

These structures served as the starting point for calculations using the XED force field in which the whole ensemble was minimized to $<0.01 \mathrm{rms}$ (conjugate gradient with no constraints). ${ }^{8-11}$ All carboxylate and ammonium ions were charged at $1 / 8$ th full charge to account for partial solvation effects. After minimization, the interaction energy (IE) between the two triple helix units was calculated and consisted of both coulombic and van der Waals components. This energy included all intermolecular terms between each triple helix unit. Intramolecular terms and energies between strands in the same triplehelix bundle were not included. The results for several combinations of recognition elements are summarized in Table S1. The modelled interface for $\mathbf{1 a}$ is shown in Figure 1 (Table S1, entry 1). Three aromatic ring pairs adopted face-to-face orientations and one hydrogen bond was observed at the interface. The structure was tested by reorienting the aromatics in an edge-to-face arrangement and then re-minimizing (Table S1, entry 2). The resulting interface structure reverted back to face-to-face interactions with similar interface energy (Figure S3). The interface of $\mathbf{1 b}$ exhibited either edge-to-face (Table S1, entry 3; Figure S4) or displaced angled face-to-face interactions. The interface energy of 1c was much lower (Table S1, entry 4).

The TOC modeling graphic was generated using PyMOL. ${ }^{12}$ 
Table S1. Calculated interaction energies for different self-assembly recognition pairs

\begin{tabular}{|c|c|c|c|}
\hline Entry & Self-assembly pair & $\begin{array}{c}\text { Interaction Energy } \\
\text { (kcal/mol): } \\
\text { total IE } \\
\text { coulombic } \\
\text { van der Waals }\end{array}$ & Comments \\
\hline 1 & $\begin{array}{l}\text { Phe-pentafluorophenylalanine } \\
\text { (starting with face to face } \\
\text { orientation) model of } \mathbf{1 a}\end{array}$ & $\begin{array}{l}\mathbf{- 5 5 . 2} \\
-15.0 \\
-40.2\end{array}$ & \\
\hline 2 & $\begin{array}{l}\text { Phe-pentafluorophenylalanine } \\
\text { (starting T-shaped orientation) } \\
\text { model of } \mathbf{1 a}\end{array}$ & $\begin{array}{l}\mathbf{- 5 6 . 4} \\
-15.2 \\
-41.2\end{array}$ & $\begin{array}{c}\text { Minimizes back } \\
\text { to face-to-face } \\
\text { orientations }\end{array}$ \\
\hline 3 & Phe-Phe model of $\mathbf{1 b}$ & $\begin{array}{l}-49.2 \\
-7.0 \\
-42.2\end{array}$ & $\begin{array}{l}\text { Minimizes } \\
\text { towards edge-to- } \\
\text { face orientations }\end{array}$ \\
\hline 4 & Phe-Leu model of $\mathbf{1 c}$ & $\begin{array}{l}-32.5 \\
-5.6 \\
-36.9\end{array}$ & \\
\hline
\end{tabular}

Figure S2. (a) Minimized interface of 1a showing close aromatic/aromatic stacking and H-bonding distances in angstroms. (b) Space filling model of $\mathbf{1 a}$ interface with individual strands colored in blue, yellow, and red.
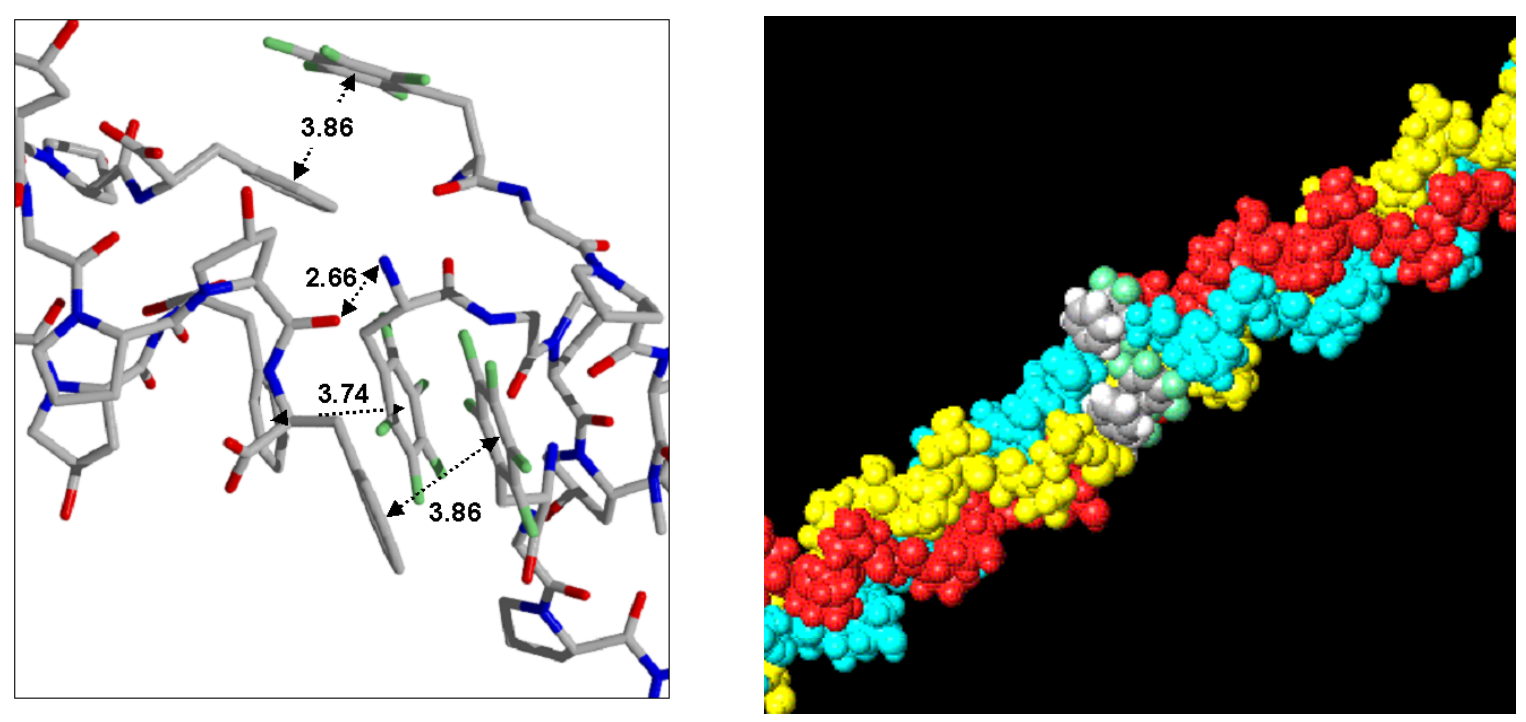


$$
\text { S - } 5
$$

Figure S3. Test of 1a interface by starting minimization in an edge-to-face orientation.
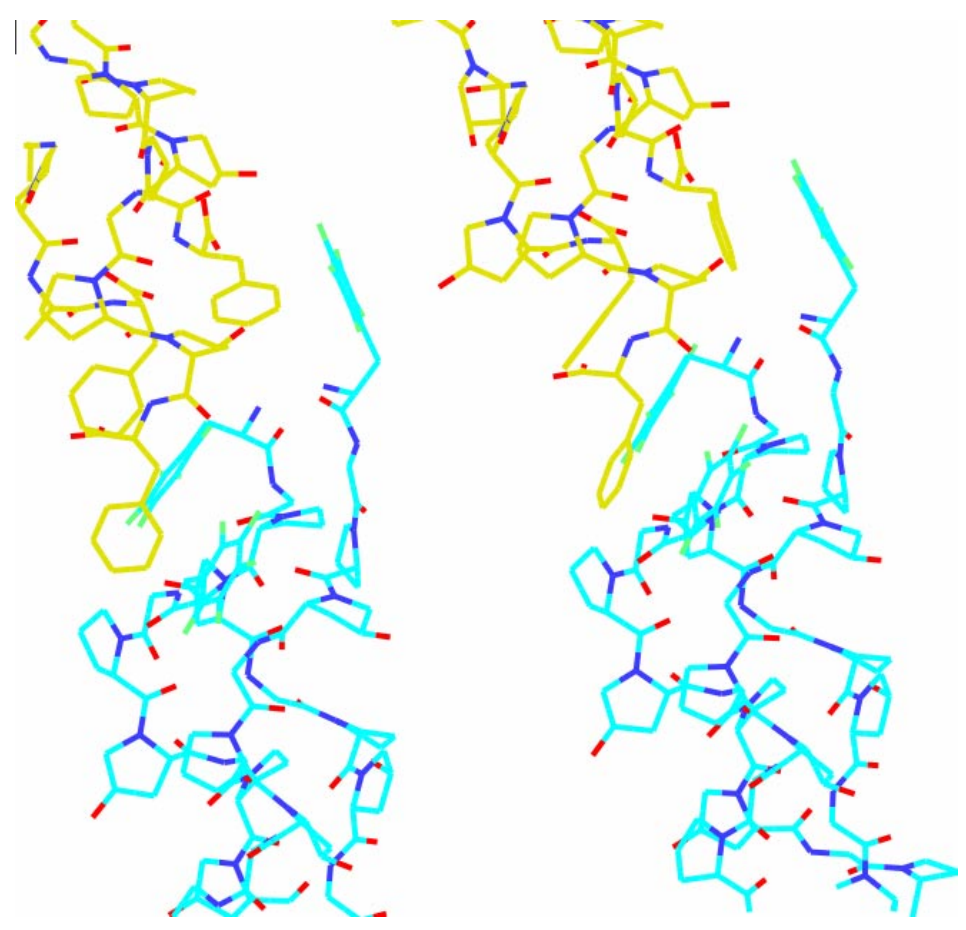

1a Start

All Phe (Edge)

turned into

$\mathrm{F}_{5}$ Phe (Face) 1a End

All Phe/F 5 Phe

reverted to

symmetric

Face/Face 


$$
\text { S - } 6
$$

Figure S4. Modeled interface of $\mathbf{1 b}$ starting with face-to-face interaction and ending with edge-to-face.

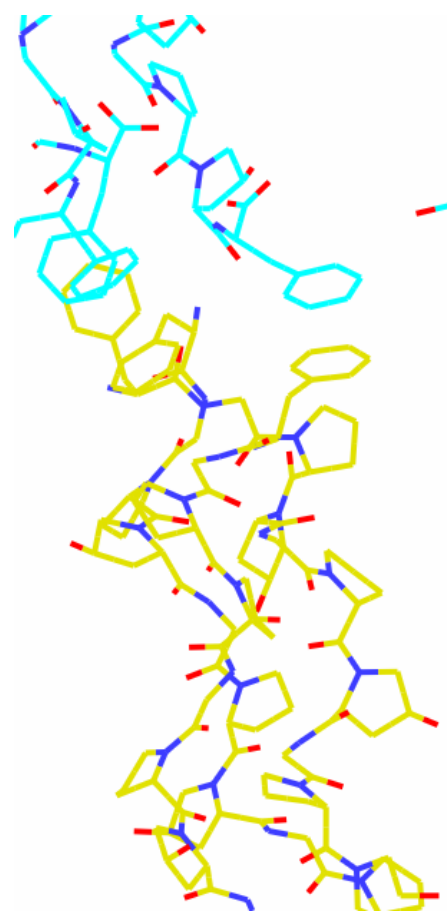

1b Start

Ar/Ar all symmetric Face/Face

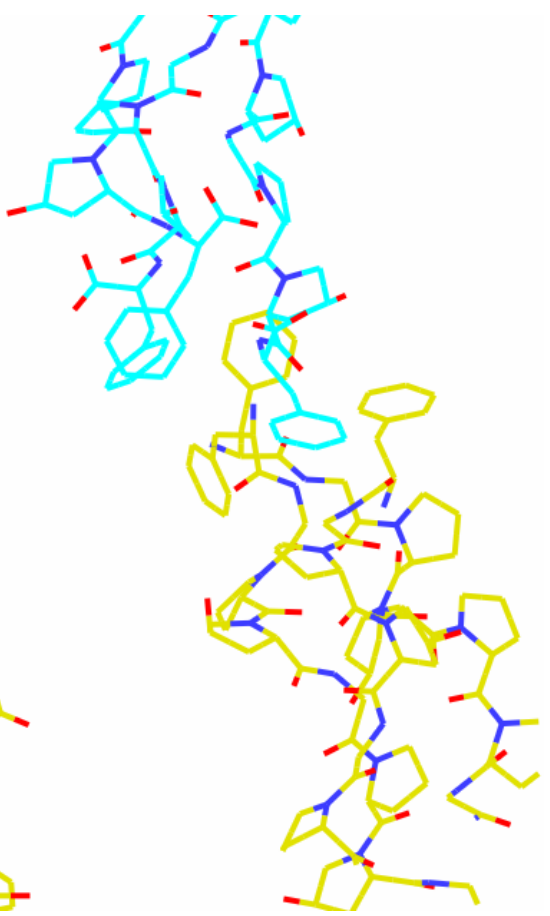

$1 b$ End

$\mathrm{Ar} / \mathrm{Ar}$ all Edge/Face

Circular Dichroism (CD) Spectroscopy. Peptides solutions $(0.25 \mathrm{mM}$ and 0.013 $\mathrm{mM}$ in water) were stored at $4{ }^{\circ} \mathrm{C}$ for $24 \mathrm{~h}$ for triple helix formation. $\mathrm{CD}$ spectra were measured at $25^{\circ} \mathrm{C}$ on a Jasco $\mathrm{J}-710$ instrument using $0.1 \mathrm{~cm}$ path length cells by signal averaging 10 or 20 scans at a scan speed of $100 \mathrm{~nm} / \mathrm{min}$ (Figure S5). CD melting curves were obtained on an Aviv 215 spectrometer equipped with a Peltier temperature control system. The ellipticity at $225 \mathrm{~nm}$ was monitored from 20 to $100{ }^{\circ} \mathrm{C}$, at a rate of 1 ${ }^{\circ} \mathrm{C} / \mathrm{min}$, with increments of $3{ }^{\circ} \mathrm{C}$, equilibration time of $5 \mathrm{~min}$ and $0.1-\mathrm{cm}$ path length. 
Figure S5. CD data of $1 \mathbf{a}(0.25 \mathrm{mM})$ in water. (Inset 1a, $0.013 \mathrm{mM})$.

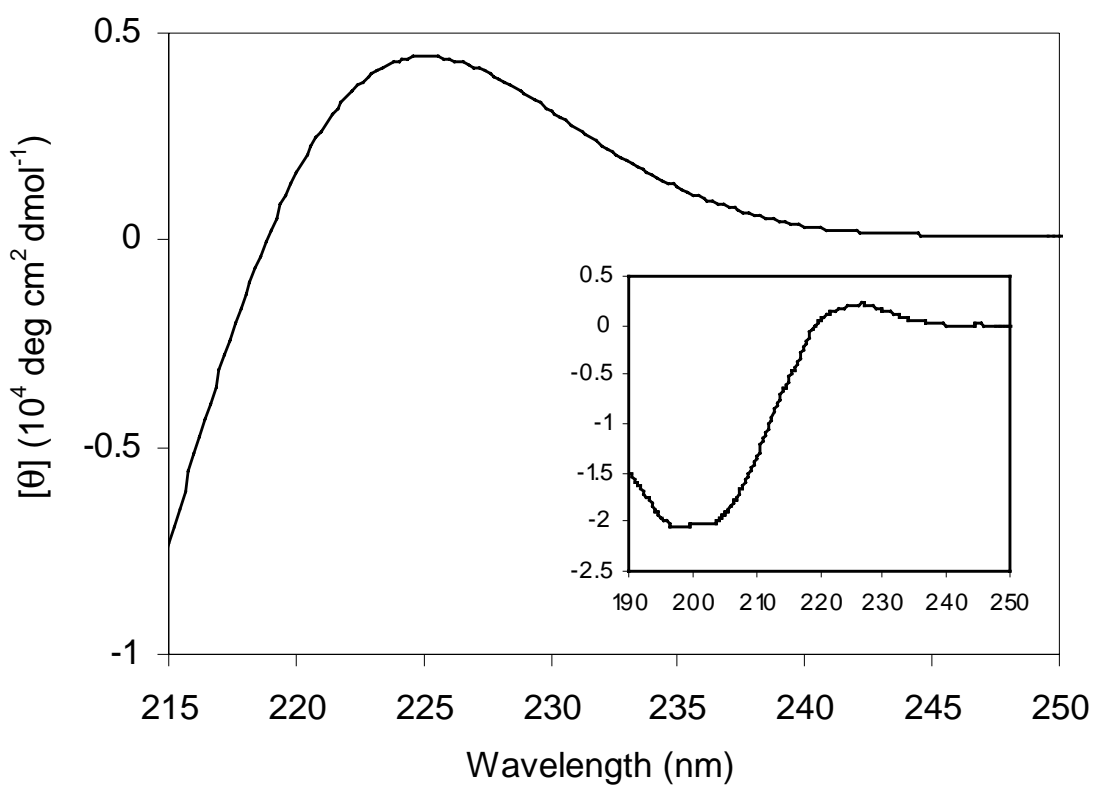

Scanning Electron Microscopy (SEM). SEM images were taken at the University of Miami with a Philips XL30 ESEM-FEG environmental scanning electron microscope in SEM mode. Aqueous solutions of peptide $1 \mathbf{a}(0.1 \mathrm{mg} / \mathrm{mL})$ were filtered through 0.4$\mu \mathrm{m}$ filters, deposited on an SEM stub and air-dried at room temperature. Images were taken at at $5 \mathrm{kV}$. These images indicated agglomeration of microfibrillar material (Figure S6). In order to observe an individual microfibrils, higher magnification and greater dilution was needed. 
Figure S6. SEM images of self-assembled peptide 1a, $\times 400$ (a) and $\times 1600$ (b)

(a)

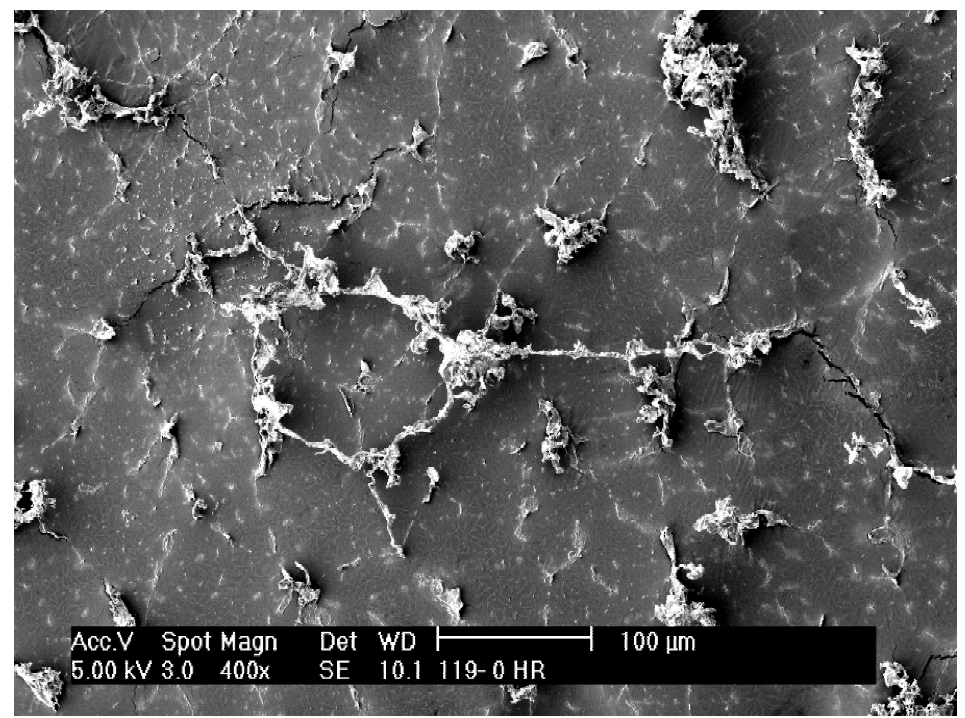

(b)

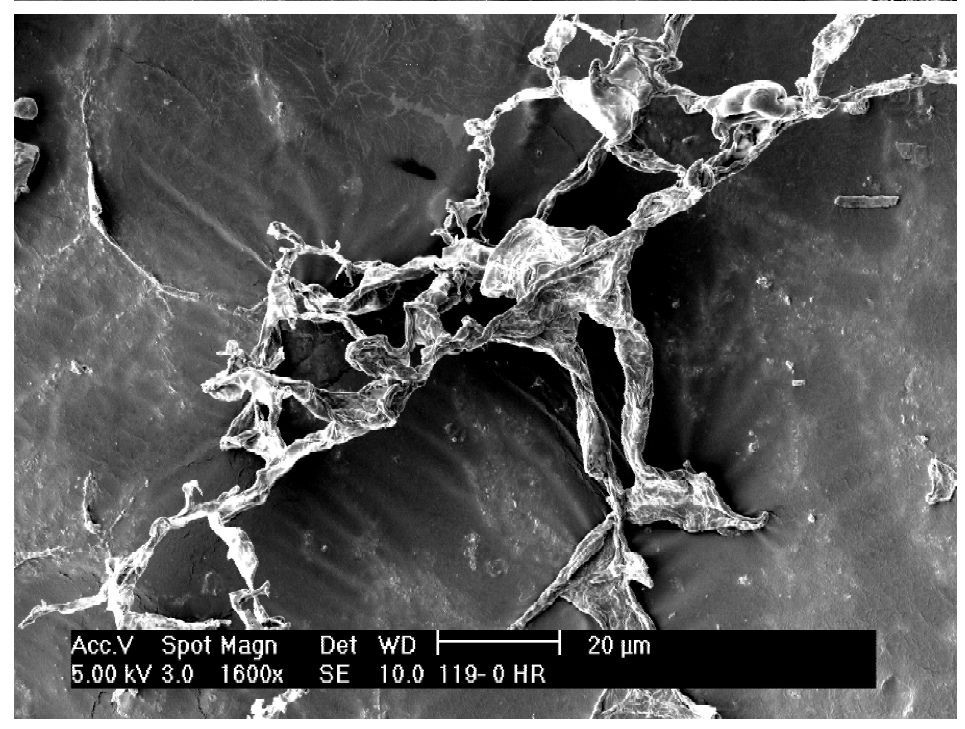

Transmission Electron Microscopy (TEM). TEM images were taken at the University of Miami with a TEM Philips EM 300. Aqueous solutions of peptide 1a $(0.05$ $\mathrm{mg} / \mathrm{mL}$ ) were filtered through $0.4-\mu \mathrm{m}$ filters and deposited on copper grids coated with carbon films. The solutions were dried at $40{ }^{\circ} \mathrm{C}$ and images shown in Figures $3 \mathrm{a}$ and S7a were taken. The image in Figure S7b was obtained similarly but the sample was negatively stained with uranyl acetate. Images were recorded at $80 \mathrm{kV}$.

Murine arteries were stained with $2 \%$ glutaraldehyde and placed inside epoxy blocks for TEM. Thin sections of the arteries inside the epoxy blocks (around 200-500 nm in size) were cut using a diamond section tool. They were mounted on the copper grids and images were recorded at $60 \mathrm{kV}$. 
Figure S7. TEM images of self-assembled peptide 1a, unstained (a) and stained (b)
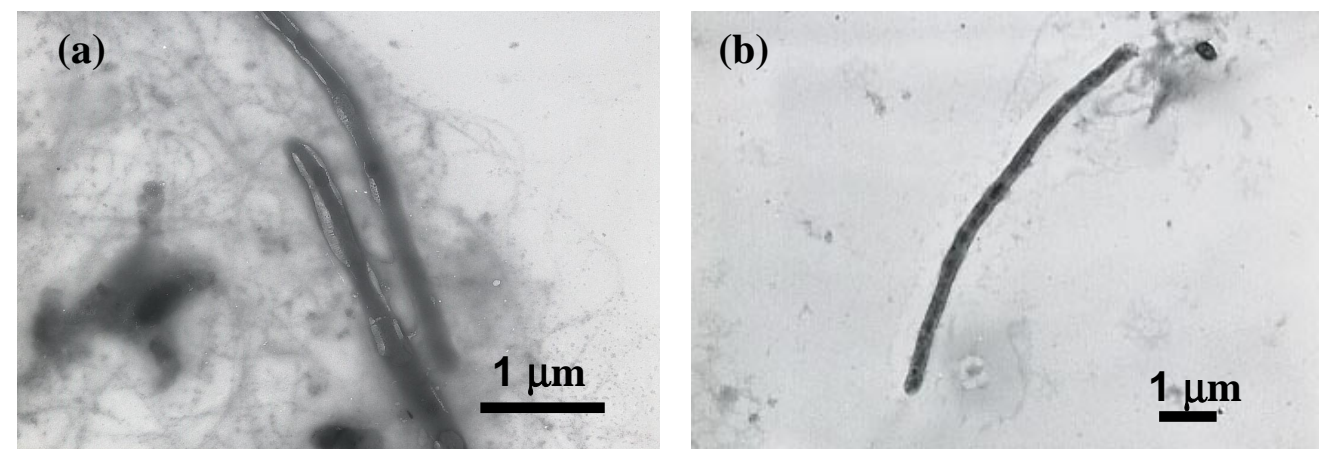

Proton NMR Spectroscopy. Proton NMR spectra (Figure S8) of $1 a\left(1 \mathrm{mM}\right.$ in $\mathrm{D}_{2} \mathrm{O}$ incubated at $4{ }^{\circ} \mathrm{C}$ for $24 \mathrm{~h}$ ) were collected on a DMX-600 NMR spectrometer (Bruker Biospin, Inc., Billerica, MA 01821-3991) equipped with a triple resonance $\left({ }^{1} \mathrm{H},{ }^{13} \mathrm{C},{ }^{15} \mathrm{~N}\right)$, triple axis, gradient probe. A one-dimensional NOESY, with presaturation during the recycle delay and the mixing time, was used to collect the data. The temperature was raised in increments of $10{ }^{\circ} \mathrm{C}$ and the spectra were measured after 15 min equilibration.

Figure S8. Variable temperature ${ }^{1} \mathrm{H}$ NMR spectra of $\mathbf{1 a}\left(1 \mathrm{mM}\right.$ in $\left.\mathrm{D}_{2} \mathrm{O}\right)$.

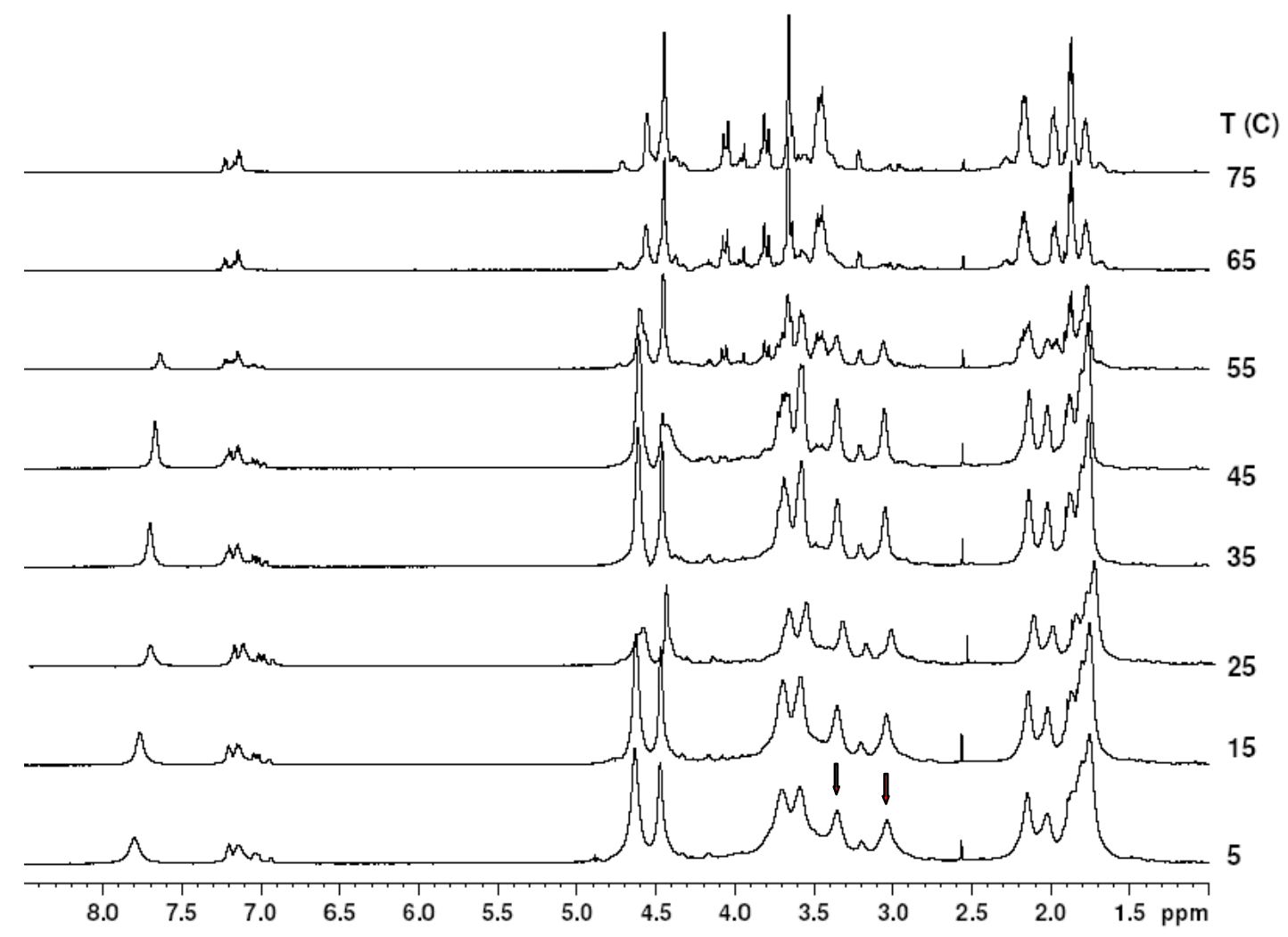


Dynamic Light Scattering (DLS). DLS measurements (Figure S9) were made on a Malvern Zetasizer Zen 1600 instrument equipped with a 633-nm laser (He-Ne, $4.0 \mathrm{~mW}$ ) and backscatter detection at $173^{\circ}$. Solutions of peptides $1 \mathbf{a}$ and $\mathbf{2 a}(0.5 \mathrm{mg} / \mathrm{mL}$ in water $)$ were heated at $70{ }^{\circ} \mathrm{C}$ for $10 \mathrm{~min}$, filtered hot through a $0.45-\mu \mathrm{m}$ filter and measured in 1.0-cm plastic cuvettes when the solutions reached room temperature $(\mathrm{t}=0)$ and after 24 h.

Figure S9. DLS measurements of peptides $\mathbf{1 a}(\mathbf{A})$ and $\mathbf{2 a}(\mathbf{B})(0.5 \mathrm{mg} / \mathrm{mL}$ in water heated at $70^{\circ} \mathrm{C}$ for $10 \mathrm{~min}$ and filtered through a $0.45-\mu \mathrm{m}$ filter) measured at $\mathrm{t}=0$ (red) and after $24 \mathrm{~h}$ (green).
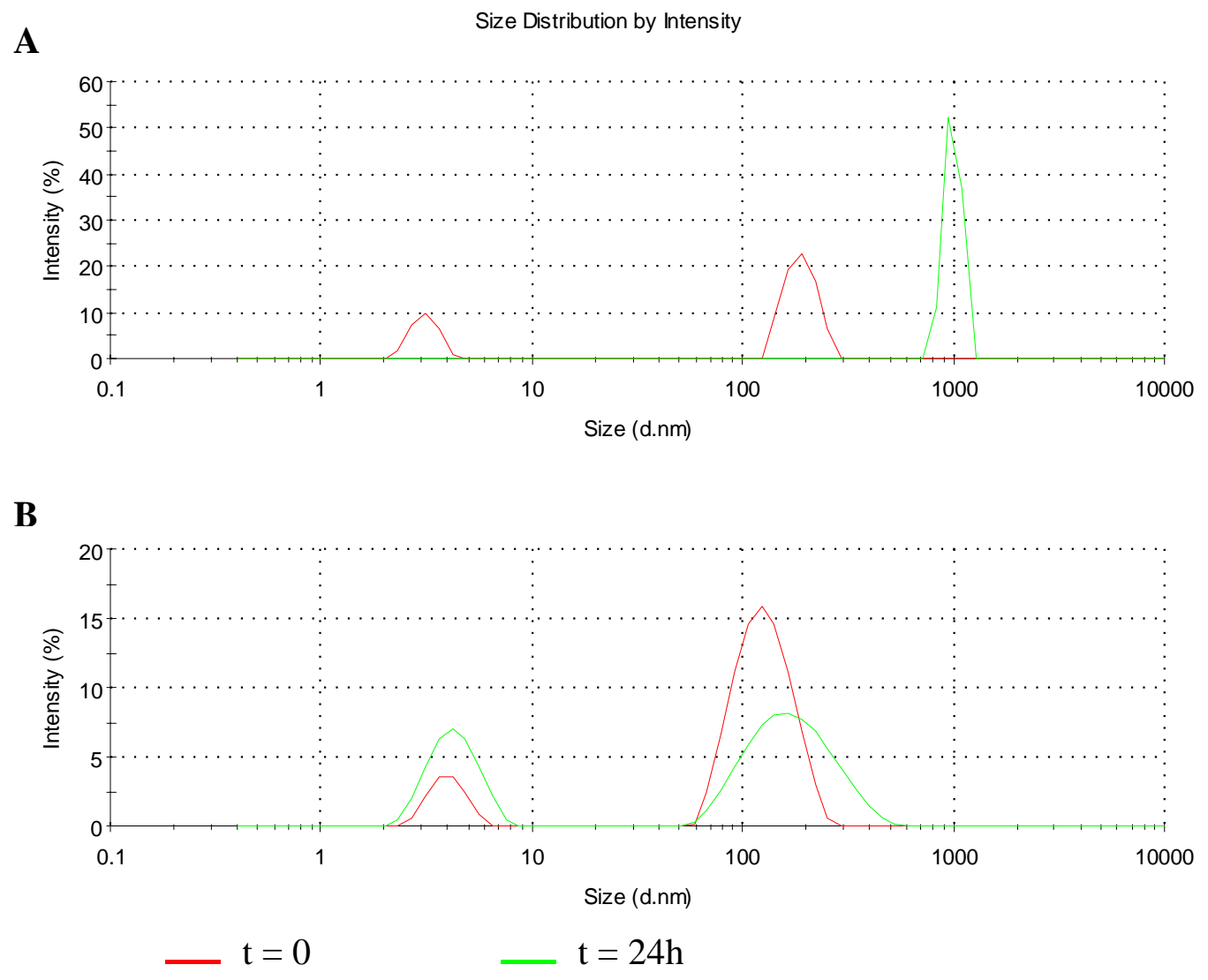
Platelet Aggregation Studies. The conditions for peptide preparation for platelet aggregation studies are contained in Table S2. Peptides were dissolved in PBS (pH 7) or water (final $\mathrm{pH} \mathrm{5}$ ) to a concentration of $2 \mathrm{mg} / \mathrm{mL}$. Some samples were heated in a water bath $\left(70^{\circ} \mathrm{C}\right)$ for $10 \mathrm{~min}$, filtered through a $0.45-\mu \mathrm{m}$ filter and incubated for $24 \mathrm{~h}$ or 7 days at $4{ }^{\circ} \mathrm{C}$. UV measurements at $215 \mathrm{~nm}$ before and after filtration indicated no loss of peptide. The rest of the samples were incubated for $24 \mathrm{~h}$ or 7 days at $4{ }^{\circ} \mathrm{C}$.

Table S2. Conditions of peptides preparation and results for platelet aggregation studies.

\begin{tabular}{|c|c|c|c|c|c|}
\hline Peptide & Solvent & Conditions* & $\mathrm{pH}$ & $\begin{array}{c}\text { Incubation } \\
\text { time }\end{array}$ & $\mathrm{EC}_{50} \pm \mathrm{SEM}(\mu \mathrm{g} / \mathrm{mL})$ \\
\hline $\begin{array}{c}\text { collagen } \\
(\mathbf{\square})\end{array}$ & & & & $0.25 \pm 0.02$ \\
\hline $\mathbf{1 a}(\boldsymbol{\Delta})$ & PBS & & 7 & 7 days & $0.37 \pm 0.06$ \\
\hline $\mathbf{1 a}(\boldsymbol{\nabla})$ & PBS & $\mathrm{H}+\mathrm{F}$ & 7 & 7 days & $2.7 \pm 0.20$ \\
\hline $\mathbf{1 a}(\bullet)$ & PBS & $\mathrm{H}+\mathrm{F}$ & 7 & $24 \mathrm{~h}$ & $9.2 \pm 0.82$ \\
\hline $\mathbf{1 a}(\bullet)$ & water & & 5 & $24 \mathrm{~h}$ & $1.4 \pm 0.27$ \\
\hline $\mathbf{2 b}(\square)$ & PBS & $\mathrm{H}+\mathrm{F}$ & 7 & $24 \mathrm{~h}$ & Not Active \\
\hline
\end{tabular}

* $\mathrm{H}$, heated at $70^{\circ} \mathrm{C}$ for $10 \mathrm{~min}$; F, filtered through a $0.45-\mu \mathrm{m}$ filter.

Human platelet-rich plasma (PRP) concentrate from healthy volunteers was purchased from Biological Specialties, Inc. (Colmar, PA). The PRP was not older than 5 $\mathrm{h}$, since PRP that was $24 \mathrm{~h}$ old gave considerably attenuated responses to collagen and agonist peptide 1a. PRP was centrifuged at $730 \mathrm{~g}$ for $15 \mathrm{~min}$. The platelet pellet was washed twice in CGS buffer (13 mM sodium citrate, $30 \mathrm{mM}$ glucose, $120 \mathrm{mM} \mathrm{NaCl}, \mathrm{pH}$ 6.5) containing $1 \mathrm{U} / \mathrm{mL}$ apyrase (grade V, Sigma-Aldrich) and resuspended in Tyrode's buffer $\left(140 \mathrm{mM} \mathrm{NaCl}, 2.7 \mathrm{mM} \mathrm{KCl}, 12 \mathrm{mM} \mathrm{NaHCO} 3,0.76 \mathrm{mM} \mathrm{Na} \mathrm{HPO}_{4}, 5.5 \mathrm{mM}\right.$ dextrose, $5.0 \mathrm{mM}$ Hepes, $0.2 \%$ BSA, pH 7.4). The "washed" platelets were diluted to $3 \mathrm{x}$ $10^{8}$ platelets $/ \mathrm{mL}$ and kept $>45 \mathrm{~min}$ at $37{ }^{\circ} \mathrm{C}$ before use. For assay, we added $105 \mu \mathrm{L}$ of washed platelets, $2 \mathrm{mM} \mathrm{CaCl}_{2}$, and $2.5 \mathrm{mM}$ of fibrinogen to a 96-well microtiter plate. Platelet aggregation was initiated by the addition of serial concentrations of native collagen fibrils (equine type I; 92\% identity with human collagen sequence; Chrono-log Corp., Havertown, PA) or test peptides. Buffer was added to one set of control wells. The assay plate was stirred constantly and intermittently placed in a microplate reader (Softmax, Molecular Devices, Menlo Park, CA) to read optical density $(650 \mathrm{~nm}$ ) at 0 and 5 min after the addition of the compound solutions. Aggregation was calculated as the decrease in optical density between the time- 0 and 5-min measurements and expressed as percent of aggregation. Inhibition of platelet aggregation induced by collagen or 1a was obtained using integrin GPIIb/IIIa antagonist elarofiban. ${ }^{13}$ 


\section{References and Notes}

(1) Holmgren, S. K.; Bretscher, L. E.; Taylor, K. M.; Raines, R. T. Chem. Biol. 1999, 6, 63-70.

(2) This extinction coefficient was determined for control peptide $\mathbf{2 b}$.

(3) Fmoc Solid-Phase Peptide Synthesis A Practical Approach: Chan, W. C.; White, P.D., Ed.; Oxford University, New York, 2003.

(4) Bella, J.; Eaton, M.; Brodsky, B.; Berman, H. M. Science 1994, 266, 75-81.

(5) Jorgensen, W. L.; Tirado-Rives, J. J. Am. Chem. Soc. 1988, 110, 1657-1666.

(6) Qui, D.; Shenkin, P. S.; Hollinger, F. P.; Still, C. W. J. Phys. Chem. A 1997, 101, 3005-3014.

(7) MacroModel, 9.0, 2005, Schrödinger, Inc., 1500 SW First Ave., Suite 1180, Portland, OR 97201.

(8) Hunter, C. A.; Sanders, J. K. M. J. Am. Chem. Soc. 1990, 112, 5525-5534.

(9) Vinter, J. G. J. Comp.-Aid. Mol. Design 1994, 8, 653-668.

(10) Vinter, J. G. J. Comp.-Aid. Mol. Design 1996, 10, 417-426.

(11) Chessari, G.; Hunter, C. A.; Low, C. M. R.; Packer, M. J.; Vinter, J. G.; Zonta, C. Chem. Eur. J. 2002, 8, 2860-2867.

(12) DeLano, W. L. The PyMOL Molecular Graphics System 2002, DeLano Scientific, San Carlos, CA (http://www.pymol.org).

(13) Hoekstra, W. J.; Maryanoff, B. E.; Damiano, B. P.; Andrade-Gordon, P.; Cohen, J. H.; Costanzo, M. J.; Haertlein, B. J.; Hecker, L. R.; Hulshizer, B. L.; Kaufman, J. A.; Keane, P.; McComsey, D. F.; Mitchell, J. A.; Scott, L.; Shah, R. D.; Yabut, S. C. J. Med. Chem. 1999, 42, 5254-5265. 